\title{
The relationship between teacher burnout and organizational socialization among English language teachers
}

\author{
Çiğdem Güneş ${ }^{\text {a }}$ (iD), Hacer Hande Uysal ${ }^{\text {b }}$ (iD \\ ${ }^{a}$ Gazi University, Gazi Faculty of Education, Teknikokullar, Ankara, 06500 Turkey \\ ${ }^{b}$ Hacettepe University, Faculty of Education, Beytepe, Ankara, 06800 Turkey
}

\section{APA Citation:}

Güneş, C.., \& Uysal, H. H. (2019). The relationship between teacher burnout and organizational socialization among English language teachers. Journal of Language and Linguistic Studies, 15(1), 339-361.

Submission Date: 04/12/2018

Acceptance Date: 27/03/2019

\begin{abstract}
This study aimed to investigate EFL (English as a foreign language) teachers' burnout and organizational socialization levels, and any possible relationship between these two aspects by employing Richmond, Wrench and Gorham's (2001) Teacher Burnout Scale and Erdoğan's (2012) Organizational Socialization Scale as quantitative tools. The study further explored the causes of teacher burnout and unsuccessful organizational socialization through a semi-structured interview as a qualitative tool. The results revealed that teachers had a low level of burnout and a high level of organizational socialization, and that there is a negative correlation between teacher burnout and organizational socialization. The interviews indicated that independent of the EFL teachers' burnout levels; the major issues that led to burnout were pre-service education, heavy workload, poor administrative and collegial support, and students' low motivation and misbehaviors.
\end{abstract}

(C) 2019 JLLS and the Authors - Published by JLLS.

Keywords: English language teaching; novice teachers; organizational socialization; teacher burnout; teacher socialization; teaching English as a foreign language

\section{Introduction}

Once a teacher starts teaching, many changes occur in his/ her life. Novice teachers find themselves in a situation where they face many challenges, not being sure how to deal with them. In addition, teachers often start their teaching career with high idealism and expect high outcomes; however, after they start teaching, they realize the huge gap between their ideals and the real teaching environment (Friedman, 2000). As a result, most teachers feel confused and become stressed; yet, they rarely get the necessary help to orientate and efficiently socialize at this initial stage (Schlichte, Yssel \& Merbler, 2005). Consequently, the teachers who are not sufficiently supported and cannot adequately socialize during their induction phase are often confronted with problems such as teacher inefficacy, disbelief in one's teaching competence, self-concerns about teaching, school reluctance, reality shock, job stress and even the first signs of teacher burnout (Boz, 2008; British Council, 2013; Caspersen \& Raaen, 2013;

\footnotetext{
* Corresponding author. Tel.: +0-544-743-0628

E-mail address: ccigdem.gunes@gmail.com
} 
Farrell, 2012; Flores \& Day, 2006; Gianakaki, Hobson, \& Malderez, 2011; Munthe, 2003; Rinke, 2008; Schlichte et al., 2005; Shin, 2012; Urzua, 1999; Walsdorf \& Lynn, 2002).

Having been an important factor affecting teacher efficiency, teacher burnout and its reasons have been largely investigated; however, almost no studies focused on the relationship between teacher socialization and burnout. Therefore, the current study examined teacher burnout with relation to teachers' organizational socialization. In addition, the study aimed to go deeper and discover the factors leading to the problems in EFL teachers' socialization processes and burnout. The study particularly focused on EFL teachers because this group of teachers faces additional burdens in their inductive year, resulting especially from demotivated students who do not see any reason to learn a foreign language that is not used for any purposes out of the classroom (British Council, 2003). Therefore, the results of this study can help us better understand how EFL teachers experience their organizational socialization process and if this has any connections with teacher burnout. The results of the study can also provide an insight into how teachers feel during their first year in their profession, thus may help teacher educators and school administrators develop effective coping strategies to successfully integrate novice EFL teachers into their new "niche" by showing them ways to handle their socialization process and avoid burnout.

\subsection{Literature Review / Theoretical Background}

\subsubsection{Teacher Socialization}

In their first year, novice teachers find themselves in a new environment involving both positive and negative influences on their teacher self to which they have to adapt themselves and gradually socialize. However, socialization is easier said than done as it is a difficult and ongoing process teachers experience through their entire career path. As Altan (1998) puts forward, "students do not become teachers ... the minute the ink dries on their diplomas" (p. 416), but it takes some time for them to become experts in their profession. It should be borne in mind that student teachers spend more time as a student than a teacher; thus, it is not easy for them to transform their identity from that of a student to that of a teacher (Kanno \& Stuart, 2011). This transformation takes place during the socialization process of teachers which involves developing a sense of task competence, work role clarity, realistic expectations about the job, and successful interpersonal relationships which will be gained over a certain span of time (Adkins, 1995).

To help teachers successfully socialize and minimize attrition, there is a need to appropriately induce teachers to their teaching positions and to their institutions. There is evidence that teachers desire to feel a sense of trust and openness, receive feedback, and be confronted with challenges with which they can cope when they enter their new school (Fottland, 2004). For the purpose of properly inducing teachers to the school environment, administrators, teachers, and education programs have to collaborate (Walsdorf \& Lynn, 2002). If teachers are welcomed by supportive colleagues, administrators, and social organizational conditions, they will surely have positive experiences (Weiss, 1992). Meanwhile, an assisting environment with collaboration among teachers would reduce teacher burnout while it aids professional development and job satisfaction (Munthe, 2003). Novice teachers need a backing environment in which leadership is shared and decision making processes are transparent with the aim of effectively affiliating teachers into the work environment (Ewing \& Smith, 2003).

However, unfortunately "supportive environments are the exception rather than the rule" (Farrell, 2012, p. 436). Therefore, teachers often face problems during organizational socialization, which may lead to teacher burnout. As stated by Maslach et al. (2001), "the greater the gap, or mismatch, between the person and the job, the greater the likelihood of burnout; conversely, the greater the match (or fit), the greater the likelihood of engagement with work" (p. 413). Consequently, to make teachers feel that there is harmony between them and their work, the induction should follow planned and well-developed 
steps to successfully integrate teachers into their new environment. A proper induction and socialization are necessary to retain teachers in their jobs (Smethem, 2007; Schlichte et al., 2005; Walsdorf \& Lynn, 2002) and to prevent burnout in the early stages of the teaching career.

\subsubsection{Teacher Burnout}

Teacher burnout has often been linked to years of overwork, which causes veteran teachers to feel exhausted and emotionally stressed (Brenninkmejer, Vanyperen, \& Buunk, 2001). However, novice teachers are also prone to burnout, which means that burnout is not only restricted to veteran teachers but it can also develop in the first years of employment (Goddard \& O'Brien, 2004). Beginning teachers more often have feelings of anxiety due to the fact that they are inexperienced in their fields (Chang, 2009). For example, if they constantly fail in classroom management and in coping with students' disruptive behaviors, burnout may occur (Hong, 2010). In addition, overwork, dissatisfaction with the working position and not feeling to belong to the workplace are also important reasons which lead to high levels of burnout (Maslach, 2003). Fairness, the organizations' values, role conflict and role ambiguity, lack of social support (Goddard \& O'Brien, 2004), lack of support from supervisors (Grayson \& Alvarez, 2008; Leiter \& Maslach, 1988; Rinke, 2008; Skaalvik \& Skaalvik, 2009), lack of feedback and praise, little participation in decision making, and lack of teacher autonomy (Maslach et al., 2001) are other reasons found behind burnout.

Time pressure, fear of violence and poor opportunities for promotion (Brenninkmejer et al., 2001), salary (Rinke, 2008; Weiss, 1999), being aware of little professional prestige, holding the same position for a long time (Cano-Garcia et al., 2005), excessive paperwork, large schools with overcrowded classrooms, the lack of equipment, students' behavioral problems, and isolation, and poor social relations (Hakanen, Bakker, \& Schaufeli, 2006) are found as other burnout triggers, which indicate the close connection between work environment and burnout.

That is, burnout, which was found to comprise three factors, namely exhaustion, cynicism, and inefficacy, is caused by a misfit between the work environment and the individual (Maslach, 2003; Maslach et al., 2001). In this sense, burnout is often a problem occurring in the job context, connected to working conditions and social relationships, which indicate the importance of successful organizational socialization to prevent burnout.

\subsubsection{Studies on Teacher Burnout and Socialization}

Despite the numerous studies on teacher burnout and teacher socialization separately, the literature comprising these topics in relation to each other is scarce. Although there are studies that deal with burnout and draw conclusions with regard to socialization or vice versa in fields other than teaching such as nursing (Taormina \& Law, 2000), human services (Liang \& Hsieh, 2008), and manufacturer workers (Gao, 2013), studies which directly combine teacher burnout and organizational socialization are almost non-existing, except for Lynn (2013). Lynn's study examined how academic optimism, teacher socialization, and teacher cohesiveness were related to teacher burnout. A total of 98 elementary school teachers completed the Maslach Burnout Inventory - Educators Survey, the Teacher Academic Optimism Scale, Teacher Socialization Scale, and Teacher Cohesiveness Scale. The results showed that academic optimism and cohesiveness had a negative relationship with emotional exhaustion and depersonalization while they had a positive relationship with personal accomplishment. In contrast, socialization was reported not to have a significant relationship with the three burnout dimensions that are emotional exhaustion, depersonalization, and personal accomplishment which was contradictory to the findings of Liang and Hsieh (2008) who claimed that organizational socialization was related to these three dimensions of burnout for employees in people-oriented professions.

Concerning particularly EFL teachers, burnout and organizational socialization were not broadly researched and not related to each other. Researchers either dealt mainly with burnout (Cephe, 2010; 
Öztürk, 2013; Unaldi et al., 2013) or socialization alone (Cantekin, 2013). Moreover, most existing studies have not considered the novice teachers under risk of burnout caused by the challenges of the beginning years and did not focus on levels of burnout from the commencement of the teaching career (Goddard \& O'Brien, 2004).

Given the scarcity of studies combining teachers' organizational socialization and burnout, and their contradictory results, the current study aims at exploring EFL teachers' organizational socialization in relation to burnout to shed further light on this area in the field. As burnout is likely to occur during the first years in one's job as well (Goddard \& O'Brien, 2004; Maslach \& Jackson, 1981), this study also attempts to look at the burnout levels of novice teachers in relation to their socialization process. Furthermore, the current study is significant in that it provides information on the sources of burnout and the factors affecting organizational socialization in the beginning of the teaching career.

\subsection{Research Questions}

In an attempt to advance the understanding of the nature of teachers' organizational socialization process in relation to their burnout levels, and to explore the effects of different variables, such as gender, age, major, educational status, teaching experience, school type, school location and school population, and weekly workload on organizational socialization and teacher burnout, the current study aims to answer the following research questions:

1. What is the organizational socialization level of EFL teachers?

2. What is the burnout level of EFL teachers?

3. Is there any relationship between EFL teachers' organizational socialization and burnout?

4. What are possible factors leading to problems in EFL teachers' socialization and burnout?

\section{Method}

\subsection{Context and Participants}

Participants in the present study were 507 Turkish EFL teachers teaching English as a foreign language in public schools where Turkish is the language of instruction. The participants were all from the same L1 background, namely Turkish. They had different educational backgrounds as they graduated from different departments such as American Culture and Literature (4\%), English Language and Literature (14\%), English Language Teaching (80\%), English Linguistics (1\%), and Translation and Interpretation (1\%). Participant teachers had varying experiences in their fields of study; they were employed in different school types (e.g. primary school, secondary school), had diverse workloads ranging between 2 and 30+ teaching hours, and they were working in schools located in varying locations (urban $(56 \%)$ or rural $(43 \%)$ ).

\subsection{Instruments}

Research instruments used in this study were the Teacher Burnout Scale and the Organizational Socialization Scale as quantitative tools, and a semi-structured interview as a qualitative tool.

\subsubsection{The Teacher Burnout Scale}

In order to identify EFL teachers' burnout levels, the Teacher Burnout Scale developed by Richmond et al. (2001) was used. This instrument is widely accepted among researchers and addresses career satisfaction, coping with job-related stress, and attitudes towards students which are among the factors 
affecting the level of burnout. The alpha reliability estimates for the Teacher Burnout Scale are about .85 and its face validity is proved to be high enough to be used as a valid tool (Richmond et al., 2001).

This scale comprises 20 statements which participants rate on a five-point Likert scale ( 1 stands for "strongly disagree", 2 stands for "disagree", 3 represents "neutral", 4 means "agree", and finally, 5 means "strongly agree") (Richmond et al., 2001) and divides the participants into four different burnout levels which are few, strong, substantial, and severe:

0-36 stands for few burnout feelings;

36-55 stands for strong burnout feelings being not a serious problem;

56-70 stands for substantial burnout feelings necessitating help to deal with burnout;

71-80 stands for severe burnout.

\subsubsection{The Organizational Socialization Scale}

Because organizational factors usually lead to teacher stress (Byrne, 1991, as cited in Grayson \& Alvarez, 2008) which in turn evokes burnout, this study also attempted to seek some evidence for the relationship between burnout levels and organizational socialization by using Erdoğan's (2012) organizational socialization scale which consists of 24 statements which have to be rated on a five-point Likert scale. This scale comprises four dimensions (task, colleagues, organization, roles) which are postulated as the crucial factors of socialization (Haueter, Macan, \& Winter, 2003). By correlating the four burnout levels in Richmond et al. (2001) with the five dimensions of socialization in Erdoğan's scale (organizational policy, organizational aims, organizational history and language, job efficacy, and interpersonal relationships), it was aimed to figure out if there is a relationship between teacher burnout and organizational socialization.

The reliability and validity of the scale was proven by Erdoğan (2012) with the use of the KaiserMeyer-Olkin (KMO) test whose estimates were .926 which shows that the Organizational Socialization Scale is useable. Cronbach Alpha values for reliability for each of the factors of the scale were calculated, and for the whole scale the Cronbach Alpha value was found to be .898 .

Since the Organizational Socialization Scale was originally developed in Turkish the scale was translated into English by using Brislin's back translation method, which is widely used among researchers to validate instruments (Cha, Kim, \& Erlen, 2007; Dixon, 2004). Five bilingual translators translated the survey to English and then ten translators translated it back to Turkish. Lastly, the final version of the translations was scrutinized by three experts in English language teaching field.

\subsubsection{Interview}

To understand the reasons behind any possible problems with socialization and burnout, the researcher conducted semi-structured interviews with some of the participants, who were chosen through convenience sampling based on their availability and burnout scores.

Before the interview, the researcher asked five novice EFL teachers how they felt and what kind of problems they encountered in their first day and first semester as a teacher. The answers elicited were used as baseline data to help the researcher determine the actual interview questions. The answers were scrutinized and the problems the five EFL teachers mentioned were reformulated to questions to be included in the semi-structured interview in order to gain deeper insights from the participants. These five novice EFL teachers were not included in the actual interviews and the questionnaire.

Some of the questions included in the interview were also determined as a result of a literature review related to the field of teacher burnout and organizational socialization. The interview consists of 15 items. These were divided into two main sections:

1. The first section about "Teacher Socialization" included ten questions related to the induction phase, mentoring, satisfaction, problems confronted, feelings, university-school 
connection, orientation, collegial relationships, praise, school environment and other experiences as an EFL teacher.

2. The second section about "Teacher Burnout" comprised five questions, dealing with expectations regarding the teaching career, motivation, the transition from being a student to being a teacher and teachers' thoughts about their teacher training programs.

The researcher used open-ended questions to make the participants feel free to narrate their stories without being hindered by options to choose among. Further, it was aimed to elicit teachers' attitudes concerning

(a) the difficulties they had during their socialization process,

(b) what or who the main sources of their failure or success in socialization were,

(c) what or who the main sources of teacher burnout were.

\subsection{Data Collection Procedure}

The first round of the data collection involved the application of the questionnaire which was spread via ELT groups grounded in Facebook. A total of 507 responses were collected.

In the second phase of the data collection, semi-structured interviews with a total of 16 volunteered teachers (11 novice and 5 experienced) were conducted. Among these teachers, four had substantial or severe burnout, eight had strong burnout, and four had a low burnout level.

\subsection{Data Analysis}

The data gathered through the Teacher Burnout Scale and the Organizational Socialization Scale were examined with the help of SPSS (Statistical Package for Social Sciences). The following methods were used to answer the research questions:

1. To explore the organizational socialization and burnout levels of EFL teachers, descriptive statistics were used.

2. To find if there is any relationship between EFL teachers' organizational socialization and burnout, a Pearson correlation test was administered.

3. To identify possible demographic factors such as gender, age, teaching experience, school location, major, type of school, school population, amount of teaching hours, and educational status that could evoke problems in EFL teachers' socialization and burnout, t-tests and oneway ANOVAs were conducted.

4. Finally, interviews were conducted and analyzed with the principles of grounded theory. The qualitative responses from the interviews were measured in terms of thematic content of comments related to teachers' perceptions of their level of socialization and burnout. The steps of the analytic cycle (description, comparison, categorization, conceptualization, and theory development) (Hennink, Hutter, \& Bailey, 2011), were followed: Interview data were searched by topic one by one and emerging topics which were possible indicators of problems in socialization and burnout triggers were marked. The findings of the interviews were compared with each other to further explore issues and conclude on compliant patterns in the interviews. The data were categorized according to the respondents' burnout level. This was done in order to see if there were differences or similarities in the perceptions of teachers with different burnout levels in relation to their organizational socialization process. 


\section{Results and Discussion}

\subsection{Questionnaire Results and Discussion}

1. What is the organizational socialization level of EFL teachers?

The statistical results obtained from the English Organizational Socialization Scale indicated that the mean score of the Organizational Socialization Scale was 91.56 out of 120 and its standard deviation was 11.95 , that is the organizational socialization level of the participants was high which shows that teachers do not have serious troubles in the schools they work, that they feel a part of their organization, and that they probably enjoy their profession without feeling stressed by the difficulties posed by the new work environment. This implied that EFL teachers in Turkey are not confronted with any troubles that hinder their socialization.

Table 1. EFL teachers' organizational socialization level

\begin{tabular}{ccccccl}
\hline & $\mathrm{N}$ & Range & Minimum & Maximum & Mean & Std. Deviation \\
\hline $\begin{array}{c}\text { Organizational Socialization } \\
\text { Level }\end{array}$ & 503 & 65.00 & 55.00 & 120.0 & 91.56 & 11.95 \\
\hline
\end{tabular}

2. What is the burnout level of EFL teachers?

The results obtained from the Teacher Burnout Scale demonstrated that the mean score was 14.85 out of 100 and the standard deviation was 48.78, which means that the participants' burnout level was low and that they were not experiencing much symptoms of burnout. This indicates that the EFL teachers in Turkey experience the opposite feelings of burnout composed of engagement, energy, and a strong link to the profession (Bakker et al., 2008). Since engagement is claimed to produce pleasant outcomes, engaged workers are said to be optimistic about their future and able to meet their demands by participation in different organizational roles (Bakker et al., 2008).

Table 2. EFL teachers' burnout level

\begin{tabular}{ccccccc}
\hline & $\mathrm{N}$ & Range & Minimum & Maximum & Mean & Std. Deviation \\
\hline Burnout Level & 503 & 75.00 & 20.00 & 95.00 & 48.8 & 14.85 \\
\hline
\end{tabular}

2. Is there any relationship between EFL teachers' organizational socialization and burnout?

The third research question combined organizational socialization with teacher burnout to ascertain if there is a relationship between these. A Pearson correlation test was administered. As can be seen in table 3, there is a moderate negative relation $(r=-.42)$ between the teachers' level of burnout and their scores received from the English Organizational Socialization Scale. According to the data, the lower the burnout level, the higher the scores on the Organizational Socialization Scale; and the higher the burnout level, the lower the scores received on the Organizational Socialization Scale. This relationship demonstrates the existence of a negative correlation between burnout and organizational socialization. 
Table 3. Correlation between organizational socialization and burnout

\begin{tabular}{llll}
\hline & & Burnout & $\begin{array}{l}\text { Organizational } \\
\text { Socialization }\end{array}$ \\
\hline \multirow{3}{*}{ Burnout } & Pearson Correlation & 1 & $-.42^{* *}$ \\
& Sig. (2-tailed) & & .00 \\
Organizational & $\mathrm{N}$ & 503 & 503 \\
\cline { 2 - 4 } Socialization & Pearson Correlation & $-.42^{* *}$ & 1 \\
& $\mathrm{Sig}$. (2-tailed) & .00 & \\
\hline
\end{tabular}

**. Correlation is significant at the 0.01 level (2-tailed).

For the purpose of gaining more insights, the participants were divided into four different groups based on their burnout scores: few, strong, substantial, and severe. The different burnout levels of these groups were combined with the five factors of the Organizational Socialization Scale (organizational policy, organizational aims, organizational history and language, job efficacy, and interpersonal relationships). For all levels, it was found that when the level of burnout decreases, the scores on each dimension of social organization scale (organizational policy, organizational aims, organizational history and language, job efficacy, interpersonal relationships) increases.

Table 4. Descriptive statistics for teacher burnout and organizational socialization

\begin{tabular}{|c|c|c|c|c|}
\hline & & $\mathrm{N}$ & Mean & Std. Deviation \\
\hline \multirow{5}{*}{$\begin{array}{l}\text { Organizational } \\
\text { Policy }\end{array}$} & Few & 107 & 16.7477 & 2.39927 \\
\hline & Strong & 232 & 15.7069 & 2.49508 \\
\hline & Substantial & 125 & 15.0320 & 2.97553 \\
\hline & Severe & 39 & 15.5897 & 3.79555 \\
\hline & Total & 503 & 15.7515 & 2.77508 \\
\hline \multirow{5}{*}{$\begin{array}{l}\text { Organizational } \\
\text { Aims }\end{array}$} & Few & 107 & 21.4019 & 2.89717 \\
\hline & Strong & 232 & 19.5733 & 2.81674 \\
\hline & Substantial & 125 & 18.2000 & 3.25527 \\
\hline & Severe & 39 & 17.4872 & 4.12867 \\
\hline & Total & 503 & 19.4592 & 3.29218 \\
\hline \multirow{5}{*}{$\begin{array}{l}\text { Organizational } \\
\text { History and } \\
\text { Language }\end{array}$} & Few & 107 & 16.4860 & 1.97324 \\
\hline & Strong & 232 & 15.3362 & 2.24840 \\
\hline & Substantial & 125 & 14.4480 & 2.64104 \\
\hline & Severe & 39 & 13.9231 & 2.84128 \\
\hline & Total & 503 & 15.2505 & 2.47153 \\
\hline \multirow{5}{*}{ Job Efficacy } & Few & 107 & 20.9065 & 2.58637 \\
\hline & Strong & 232 & 19.5819 & 2.75747 \\
\hline & Substantial & 125 & 18.5760 & 3.11931 \\
\hline & Severe & 39 & 18.3590 & 3.55029 \\
\hline & Total & 503 & 19.5189 & 3.00119 \\
\hline \multirow{5}{*}{$\begin{array}{l}\text { Interpersonal } \\
\text { Relationships }\end{array}$} & Few & 107 & 24.1308 & 3.50494 \\
\hline & Strong & 232 & 21.2845 & 3.85855 \\
\hline & Substantial & 125 & 20.4800 & 3.78367 \\
\hline & Severe & 39 & 19.8205 & 4.82794 \\
\hline & Total & 503 & 21.5765 & 4.08837 \\
\hline
\end{tabular}


Table 5. ANOVA results based on the relationship between scores received on the organizational socialization scale and the teacher burnout scale

\begin{tabular}{|c|c|c|c|c|c|c|c|}
\hline & & $\begin{array}{l}\text { Sum of } \\
\text { Squares }\end{array}$ & df & Mean Square & $\mathrm{F}$ & Sig. & Sig. Different \\
\hline \multirow{3}{*}{$\begin{array}{l}\text { Organizational } \\
\text { Policy }\end{array}$} & Between Groups & 172.373 & 3 & 57.458 & 7.763 & .000 & \multirow{3}{*}{$\begin{array}{l}\text { Few>strong, } \\
\text { substantial }\end{array}$} \\
\hline & Within Groups & 3693.564 & 499 & 7.402 & & & \\
\hline & Total & 3865.936 & 502 & & & & \\
\hline \multirow{3}{*}{$\begin{array}{l}\text { Organizational } \\
\text { Aims }\end{array}$} & Between Groups & 756.697 & 3 & 252.232 & 26.870 & .000 & \multirow{3}{*}{$\begin{array}{l}\text { Few>strong, } \\
\text { substantial, severe } \\
\text { Strong> } \\
\text { substantial, severe }\end{array}$} \\
\hline & Within Groups & 4684.218 & 499 & 9.387 & & & \\
\hline & Total & 5440.915 & 502 & & & & \\
\hline \multirow{4}{*}{$\begin{array}{l}\text { Organizational } \\
\text { History and } \\
\text { Language }\end{array}$} & Between Groups & 314.251 & 3 & 104.750 & 18.992 & .000 & \multirow{4}{*}{$\begin{array}{l}\text { Few>strong, } \\
\text { substantial, severe } \\
\text { Strong> } \\
\text { substantial, severe }\end{array}$} \\
\hline & Within Groups & 2752.186 & 499 & 5.515 & & & \\
\hline & & & & & & & \\
\hline & Total & 3066.437 & 502 & & & & \\
\hline \multirow{3}{*}{ Job Efficacy } & Between Groups & 370.559 & 3 & 123.520 & 14.848 & .000 & \multirow{3}{*}{$\begin{array}{l}\text { Few>strong, } \\
\text { substantial, severe } \\
\text { Strong> } \\
\text { substantial }\end{array}$} \\
\hline & Within Groups & 4151.012 & 499 & 8.319 & & & \\
\hline & Total & 4521.571 & 502 & & & & \\
\hline \multirow{3}{*}{$\begin{array}{l}\text { Interpersonal } \\
\text { Relations }\end{array}$} & Between Groups & 988.467 & 3 & 329.489 & 22.211 & .000 & \multirow{3}{*}{$\begin{array}{l}\text { Few>strong, } \\
\text { substantial, severe }\end{array}$} \\
\hline & Within Groups & 7402.336 & 499 & 14.834 & & & \\
\hline & Total & 8390.803 & 502 & & & & \\
\hline
\end{tabular}

Although a negative correlation does not indicate a cause and effect relationship between burnout and organizational socialization, the results may imply that if the teachers socialize effectively, their burnout level may be kept low. This may indicate that organizational socialization could provide a richer understanding of the sources of burnout. Moreover, this finding can lead to the assumption that "burnout is ... organizationally induced and should thus be redressed through organizational change, not personal coping" (Dworkin, Saha, \& Hill, 2003, p. 109). A similar finding was reported by Liang and Hsieh (2008) who found that organizational socialization was related to the three components of burnout, namely emotional exhaustion, depersonalization, and reduced personal accomplishment indicating that organizational socialization is a predictor of burnout.

3. What are possible factors leading to problems in EFL teachers' socialization and burnout?

The fourth research question aimed to identify if demographic variables such as gender, age, major, educational status, teaching experience, type of school, school location, school population, and teaching hours were related to the scores received on the Teacher Burnout Scale and the English Organizational Socialization Scale. None of these characteristics were related with teacher burnout and organizational socialization.

\subsection{Interview Results and Discussion}

The conducted semi-structured interviews revealed the factors leading to poor socialization and burnout. The main factors mentioned by teachers were ineffective teacher training programs, poor relations with administration and poor collegial relationships, heavy workload, crowded classrooms, demotivated students and student misbehavior, location of the school, social isolation, cultural differences, being assigned courses out of their specialization, students' lack of basic knowledge in English, and the type of school, which increased the teachers' level of burnout and complicated organizational socialization. 
Most factors mentioned were similar among the teachers with different levels of burnout. Although teachers complained about similar issues they were confronted with, interestingly these factors did not affect them in the same way which resulted in different levels of burnout. An explanation might be that the teachers with lower levels of burnout knew how to handle the problems they faced and could stay away from triggers of burnout. These teachers may also have had better adaptation skills to their environments so that they could manage a more successful organizational socialization. Furthermore, their personality and expectations from the job might have been in harmony with the realities they faced. As Maslach et al. (2001) stated "the greater the gap, or mismatch, between the person and the job, the greater the likelihood of burnout; conversely, the greater the match (or fit), the greater the likelihood of engagement with work" (p. 413). Teachers' complaints according to their burnout levels can be seen in the following table:

Table 6. Complaints of EFL teachers according to their different levels of burnout

\begin{tabular}{ll}
\hline FEW (below 36) & STRONG (36-55) \\
\hline $\begin{array}{l}\text { inefficacy of the teacher training program, } \\
\text { colleagues' and administrators' unsupportive }\end{array}$ & $\begin{array}{l}\text { inefficacy of the teacher training program, } \\
\text { parents' carelessness, } \\
\text { behaviors, }\end{array}$ \\
$\begin{array}{l}\text { principal's unfair attitude, } \\
\text { political speech in the teachers' room, } \\
\text { paperwork, }\end{array}$ & workload, \\
crowded classrooms, & paperwork, \\
difficulties with the schedule & crowded classrooms, \\
& courses out of one's specialization, \\
& students' lack of knowledge \\
\hline SUBSTANTIAL (56-70) & SEVERE (71-80) \\
\hline inefficacy of the teacher training program, & inefficacy of the teacher training programs, \\
principal's negative attitude, & authoritarian principals, \\
administrative regulations, & students' low levels of English \\
paperwork, & rules of the school, \\
crowded classrooms, & crowded classrooms, \\
dissatisfaction with the profession, & cultural differences, \\
not being part of the decision-making process, & identity transformation, \\
countless changes in the education system, & lack of discipline \& student misbehavior, \\
students' lack of motivation, & demotivated students, \\
workload & dissatisfaction with the profession, \\
& nightshifts at boarding schools, workload, tiredness \\
\hline
\end{tabular}

Teachers with low (4 teachers) and a strong level of burnout (8 teachers) linked their problems to teacher training programs which failed to prepare them well enough for their career as a teacher. According to these teachers, the pre-service teacher education informed them about how things should be while the working environment showed them how things in reality are. The teachers' frustration with their pre-service education might have appeared because once teachers graduate they leave their student identity and the theoretical part of their training and enter a new environment to practice what they have learned. Teachers meet their students with the role of a "real" teacher for the first time, which may also cause some troubles during their first lessons (Clarke, Lodge \& Shevlin, 2012). The interviewed novices reported that it was hard for them to bridge the gap between theory and practice, complicating their adaptation process; and they had to learn how to teach (the practice part) from scratch in their classes.

Interviewees stated that they developed their own way of teaching by 'trial and error' in their classrooms. Previous research also suggests that novice teachers start learning while teaching (Flores \& Day, 2006), similar to the present findings. There often occurs a clash between the university education 
and reality, as theory and practice widely differ, which is described as "reality shock" (Friedman, 2000, p. 598) - a possible important factor leading to burnout. Teachers develop a better understanding of their self-concerns such as classroom management and other factors with time (Boz, 2008).

The interviewees said that they needed more practical training and a longer practicum period at the university. Some statements of teachers about the gap between university education and classroom practice can be seen below:

Universities should offer more opportunities regarding practicing (Burnout Score $=32$ ).

The two year intern teaching program should expand to a four year program equally. And real classes should be used. ... I haven't felt prepared to teach after my practicum (Burnout Score $=34)$.

It was enough with regard to theory but as we have worked with "imaginative" students, it was problematic in practice. The real school environment is really much more different. The practicum should last two years (Burnout Score $=41$ ).

I got nervous when I realized that the teacher training I received was useless in some cases. Nevertheless, after some months of trying out, I found my own way of teaching. Especially at this point veteran teachers were very helpful. During the teacher training program, nobody tells you how to fill in the class register or you are told to talk to students with behavioral problems in person but you do not get the reaction that is stated in educationbased books. You gain all these by experience. ... I think that educational faculties teach without knowing what is going on in real classrooms. You are trained as if you are going to teach in a private school located in Ankara but when you are appointed to a state school in the East, you see that your knowledge is not working here. I think that the universities should provide an education which is up-to-date. The instructors at universities have not worked in public schools and they think that we are educating the 'ideal' student (Burnout Score $=72$ ).

They added that they would welcome a program that prepares them for teaching situations in Turkey rather than European or American contexts. Apart from the fact that teacher training programs in Turkey have a small number of real classroom encounters, they are also designed based on the global theories of language teaching, aggravating the transition of novice teachers to the real settings. As Çakıroğlu and Çakıroğlu (2003) state, the priorities in each country are different and the literature and knowledge developed in another country may not help identifying the real and unique problems in another country's education system. Studies indicated that once teachers are confronted with a real classroom environment their "excitement of a first job, new classroom, and new community often lead to challenges" (Schlichte et al., 2005, p. 36) which can lead to "feelings of ineffectiveness, loneliness, and alienation from the profession" (Schlichte et al., 2005, p. 36). Interviewees mentioned that they got nervous and anxious when they entered the classroom for the first time which actually shows that they were not well enough prepared for their unique teaching situations to manage the first day of teaching.

Teachers also reported that they were not prepared by their education programs to deal with children having special needs, which is in line with previous research. Stuart and Thurlow (2000) claimed that "novice teachers report that their undergraduate education programs do not [...] adequately prepare them to face the demands of teaching in classrooms with increased numbers of children who do not speak English, children with disabilities; children with inadequate family support" (p. 113). There were teachers who wished to be in contact with their trainees at universities when they face unfamiliar 
situations to fight against the complicacies of the school as a work setting. Thirteen out of sixteen interviewees mentioned university connection as crucial.

Problems with the administration and poor collegial relationships also largely affected teachers' burnout levels and their decisions to stay in the profession. One of the two interviewees with severe burnout (Burnout Score $=78$ ) reported that there existed a kind of "sultan and slave" relationship in the school she was working for. She said "the school is ruled by monarchy and this makes me feel depressed." Teachers also expressed that the administration should not only focus on the students' but also on the teachers' satisfaction and needs. They emphasized the importance of the good relationships between administrators and teachers. It is known that "a worker may find hassles with supervisors to be a sufficient cause to dislike a worksetting" (Leiter \& Maslach, 1988, p. 307). It should also be noted that if there is no administrative support, teachers may choose to leave their positions to escape the stressful school environment leading to burnout (Quartz \& The TEP Research Group, 2003; Kersaint et al., 2007).

In contrast to the teacher with a severe burnout talking about a "sultan and slave" relationship in the schools, interviewed novices who showed a low level of burnout were found to be supported more by their colleagues and administrators and more satisfied with their jobs. Caspersen and Raaen (2013), who compared novice and experienced teachers' ability to manage their work and how this was influenced by collegial support, reported that novice teachers receive less support than experienced teachers which might be caused by the novice teachers' inability to articulate their needs. However, in this case novice teachers reported differences in administrative and collegial support, which led to various different burnout levels for them.

Teachers with higher level of burnout also related their problems to the location of the school, social isolation, being assigned to courses out of their specialization, heavy workload, students' lack of basic knowledge in English, crowded classrooms, type of school, and nightshifts. These were in parallels with the findings of Flores and Day (2006), who reported that "heavy workload, bureaucratic work, lack of support, wide variety of tasks to be performed and assessment procedures of their performance" were factors that challenged teachers.

My first problem was with the environment. I am working in a village ... I am not used to that type of environment. I felt lonely. ... For a while, I even did not want to talk with my family. I did not want to behave in a sincere manner towards my students. This made me feel unhappy... I have to teach some courses out of my specialization and this makes me feel incompetent ... and unmotivated. ... They [the students of a high school] do not have any basic knowledge. I have to teach from the beginning as if I am teaching in a primary or secondary school. ... as they do not understand English and do not even try to do so, they do not show any sign of interest (Burnout Score $=48$ ).

Interviewees complained about the students' low level of English being under their expectation. Unfortunately, it is manifested that the English competence of the majority of the students in public schools in Turkey does not develop as planned (British Council, 2013; Dogancay-Aktuna, 1998) which apparently leads to a decrease in teachers' motivation.

Participants also reported that they had difficulties to adapt themselves to the culture and customs of the region they had to work in and that a lack of school facilities complicated their induction. This was in line with Buckley et al. (2005, as cited in Rinke, 2008) who demonstrated that "the quality of school facilities is positively correlated with teachers' decisions to stay" (p. 4).

The situation got worse with the level of burnout increasing. One of the teachers with substantial burnout ( 2 in total with substantial burnout) expressed that there was no joy in the work she was doing (Burnout Score $=62$ ). The other teacher with substantial burnout reported the following: 
Unfortunately, this is not a much appreciated job. In contrast, we have to teach students who beg you for not teaching them any English. They are telling me that they do not want to stay in the classroom and that the English lessons are like a kind of punishment for them. ... I have chosen this profession voluntarily but if I had the possibility to choose my job again, I would reconsider my choice. I think that the teaching profession can be done for at least 5-6 years (Burnout Score $=59$ ).

In order to raise her satisfaction with teaching, the respondent stated that there was the necessity for a higher salary, various social activities for teachers, some occasions making her feel that teachers are worth something. It can be assumed that if teachers were provided with better alternative employments, they would immediately change their position. However, due to the difficulties caused by a low paid career, "many teachers will accept the consequences of burnout and remain in position" (Hughes, 2001, p. 289). Nevertheless, the below statements of the interviewees' support Hughes' (2001) claim that "the decision to leave can be constrained by the availability of acceptable alternative employment and geographic immobility" (Hughes, 2001, p. 289):

I have chosen the profession voluntarily but with the time passing, I discovered that I am not that excited about my job as it was the case at the beginning. If I would have the chance to choose again, I would choose another job. I did not have set a time limit for me to stay in the profession but I think that I will stay forever. ... I need to make money in a way and I do not like taking risks. If there would be a job opportunity that won't endanger my future, I would change my profession (Burnout Score $=48$ ).

As a result, the problems experienced and mentioned by the respondents of the study such as poor relations with administrators and colleagues, negative student behavior, crowded classrooms, heavy workload, regional and cultural issues, and ineffective pre-service teacher training were all external social factors. That is, similar to previous studies, the present study also indicated that "situational variables are more strongly predictive of burnout than are personal ones" (Maslach \& Goldberg, 1998, p. 65).

It is also worth considering Herzberg's Motivation-Hygiene Theory while explaining these factors. In his theory, Herzberg distinguishes between hygiene factors and motivator factors. Hygiene factors are said to compose of organizational policy, social relationships, supervision, working conditions, and salary whose absence results in dissatisfaction (Lunenburg \& Ornstein, 2008). The interviewees in the current study complained about factors related to their organization, collegial relationships, the attitude of their principals, and working conditions such as crowded classrooms and misbehaving students, which clearly represent hygiene factors that accounts for the dissatisfaction and burnout levels of the interviewees.

However, overall EFL teachers in this study were found to have lower burnout levels despite the external stressors they face in their schools. This might be due to the fact that the dissatisfying conditions could be handled or suppressed and that the positive organizational socialization they went through reduced their level of burnout. Still, the novice EFL teachers' complaints show that there are potential risk factors that could evoke burnout due to the accumulation of these negative feelings over time. That is why precautions against burnout and an ineffective organizational socialization should be taken. 


\section{Conclusions and Suggestions}

As the literature on burnout and teacher socialization was scarce and inconclusive with regard to the kind of relationship between teacher burnout and organizational socialization, the current study sought to determine whether EFL teachers' level of organizational socialization was related to burnout and what factors led to problems in novice EFL teachers' socialization process and in the occurrence of burnout. The results revealed that EFL teachers in Turkey in general have a low burnout level, but a high organizational socialization level, and that burnout scores and social organization scores of teachers were negatively correlated. That is, teachers who were successfully socialized into their organization were found to have lower levels of burnout. In contrast, teachers with a higher level of burnout were found to have gone through some difficulties in the process of socialization.

Although teachers in general had a low burnout level, the interviews revealed that EFL teachers complained about the factors, such as administrative and collegial relationships, heavy workload, quality of schools, geographical environment, which are known as common burnout triggers; therefore, in the long run these factors may increase the burnout levels of the teachers. The stressful situations novice teachers mentioned once they start teaching were also likely to complicate the process of teachers' organizational socialization.

Therefore, some precautions should be taken to prevent teacher burnout and facilitate teachers' socialization process. In order to prevent burnout, as Hebert and Worthy (2001, as cited in Flores \& Day, 2006) mentioned as the factors contributing to first year success "(i) a match between expectations, personality and workplace realities; (ii) evidence of impact; and (iii) using successful strategies to manage student behavior and enter the social and political culture of the school" could be considered (p. 220). These factors signify the importance of the teacher training program, the induction phase, an effective classroom management, and a felicitous socialization which was also expressed by the current interviewees.

First, the current teacher education programs should be innovated and planned carefully in order to generate teachers who are well prepared to teach right after graduation. An interactive teacher training program should be ensured which does not only focus on theory but also practice. Student teachers should be confronted with the reality of the working conditions in schools for the purpose of hindering reality shock. More time should be provided for micro-teaching, so that student teachers develop a sense of membership to their professions. The time spend in the practicum should be increased in order to make teacher candidates gain more experience and self-confidence. The practicum should comprise different grades, so that teacher candidates can get in contact with different age groups and see how to handle certain students. The practicum may also take place in different types of schools and even in different regions (rural/ urban). In that way student teachers could see the regional differences and prepare themselves to their possible working conditions. Finally, as Friedman (2000) proposes, teachers should be informed about the existence of "burnout" and possible coping strategies before entering the teaching profession.

In addition, with the aim of enhancing teachers' motivation, contributing to their commitment, and facilitating their integration into the school environment, the teachers should be welcomed in the organization in a friendly way, an induction program should be established, and an environment which ensures positive social relationships with parents, colleagues and the principal should be formed. Teachers should also be continuously supported through in-service seminars and courses starting from the first year of their teaching.

University-school connection is also a desired element pointed out by the teachers to reduce the stress faced at schools. Therefore, while providing in-service support, universities should also be involved in the process. As stated by Gold (1996, as cited in Walsdorf \& Lynn, 2002) "the teachers report that they 
value the university connection and find that it challenges them to remain engaged in their own professional development" (p. 193).

As Schlichte et al. (2005) and Maslach et al. (2001) suggest, supportive colleagues, administrators and mentors have to help first-year teachers to stay in the teaching profession. Principals who are communicative, supportive, guiding, and praising are said to be more committed to their profession (Weiss, 1992). Administrators who offer "an organizational environment that: (a) provides relevant job skills through training; (b) orients employees to gain a functional understanding of the organization; (c) encourages supportive coworker interaction; and (d) offers appropriate and attainable rewards" can reduce stress which is one of the most important burnout triggers (Taormina \& Law, 2000, p. 91). Therefore, the administrators and experienced teachers should be informed about what to do and how to treat their novice staff members or colleagues in order to welcome them in a friendly manner and to make them feel a part of the organization with the aid of orientation programs or seminars. These programs should provide an overview of the customs and traditions of the area the school is located in. It should introduce the school setting, philosophy, vision, rules, dominant values, and norms to the teachers. Trained mentor teachers or peer-professional helpers should be assigned for the novice teachers, so that these could guide the newcomers through their socialization process. In order to reduce conflicts and to satisfy the parents' expectations regarding their children's education, parent-school relations should also be established by not only inviting parents to parent conferences which they have to attend, but by involving parents in committees and making them organize school events in which they are actively involved.

A democratic school environment should be built in order to enable teachers to participate in collaborative decision-making. Having a say in decision-making processes would help teachers to selfactualize to some extent. Self-actualization could be reached through assigning teachers some leadership, so that they have a certain responsibility and feel part of the decision-making process. The principals should be open to new ideas, so that the teachers can come up with suggestions to be considered which would make them feel as a contributing part of the organization. Social relations in the school should be balanced. The administration and the teachers should support each other, and the principal should praise and reward teachers. Moreover, teachers should know how to build teams and how to decide on matters in groups, so that a sense of belonging is established. There should be some form of feedback and exchange of ideas, so that teachers and administrators have the possibility for improvement and change. The workload should be divided equally, so that teachers do not feel exhausted and stressed out.

Teachers should be encouraged to attend conferences to get acquainted with different teaching strategies or they should visit other schools in order to acquire additional instructional techniques which could facilitate classroom management and reduce the amount of problems perceived. Teachers should know how to cope with stress in order to avoid this burnout trigger. This could be done via the participation in seminars, the exchange of experiences among teachers, or taking some psychological support from the counselling service.

The main conclusions of the study should be presented in a short Conclusions section, which should not simply repeat earlier sections.

\section{References}

Adkins, C. L. (1995). Previous work experiences and organizational socialization: A longitudinal examination. Academy of Management Journal, 38(3), 839-862. 
Altan, M. Z. (1998). A call for change and pedagogy: a critical analysis of teacher education in Turkey. European Journal of Education, 33(4), 407-417.

Bakker, A. B., Schaufeli, W. B., Leiter, M. P., \& Taris, T. W. (2008). Work engagement: An emerging concept in occupational health. Work \& Stress: An International Journal of Work, Health \& Organisations, 22(3), 187-200.

Boz, Y. (2008). Turkish student teachers' concerns about teaching. European Journal of Teacher Education, 31(4), 367-377.

British Council (2013). Turkey National Needs Assessment of State School English Language Teaching.

Brenninkmejer, V., Vanyperen, N. W., \& Buunk, B. P. (2001). I am not a better teacher, but others are doing worse: burnout and perceptions of superiority among teachers. Social Psychology of Education, 4, 259-274.

Çakıroğlu, E., \& Çakıroğlu, J. (2003). Reflections on teacher education in Turkey. European Journal of Teacher Education, 26(2), 254-264.

Cano-Garcia, F. J., Padilla-Munoz, E. M., \& Carrasco-Ortiz, M. A. (2005). Personality and contextual variables in teacher burnout. Personality and Individual Differences, 38, 929-940.

Cantekin, Ö. F. (2013). İngilizce öğretmenlerinin örgüte uyum sorunları. Gazi ÜniversitesiEndüstriyel Sanatlar Ë̆itim Fakültesi Dergisi, 30, 1-9.

Caspersen, J., \& Raaen, F. D.(2013). Novice teachers and how they cope. Teachers and Teaching: Theory and Practice, 1-23.

Cephe, P. T. (2010). A study of the factors leading English teachers to burnout. H. U. Journal of Education, 38, 25-34.

Cha, E., Kim, K. H., \& Erlen, J. A. (2007). Translation of scales in cross-cultural research: issues and techniques. Journal of Advanced Nursing, 58(4), 386-395.

Chang, M. (2009). An appraisal perspective of teacher burnout: examining the emotional work of teachers. Education Psychology Review, 21, 193-218.

Dixon, J. K. (2004). Instrument translation process: a methods review. Journal of Advanced Nursing 48(2), 175-186.

Dogancay-Aktuna, S. (1998). The spread of English in Turkey and its current sociolinguistic profile. Journal of Multilingual and Multicultural Development, 19(1), 24-39.

Dworkin, A., Saha, L. J., \& Hill, A. N. (2003). Teacher burnout and perceptions of a democratic school environment. International Education Journal, 4(2), 108-120.

Erdoğan, U. (2012). İlköğretim okullarının bürokratik yapıları ile ögretmenlerin örgütsel sosyalleşme düzeyleri arasındaki ilişki (Malatya ili örneği). MA Thesis, İnönü University, Turkey.

Ewing, R. A., \& Smith, D. L. (2003). Retaining quality beginning teachers in the profession. English Teaching: Practice and Critique, 2(1), 15-32.

Farrell, T. S. C. (2012). Novice-service language teacher development: bridging the gap between preservice and in-service education and development. TESOL Quarterly, 46(3), 435-449.

Flores, M. A., \& Day, C. (2006). Contexts which shape and reshape new teachers' identities: A multiperspective study. Teaching and Teacher Education, 22, 219-232. 
Fottland, H. (2004). Memories of a fledgling teacher: a beginning teacher's autobiography. Teachers and Teaching: Theory and Practice, 10(6), 639-662.

Friedman, I. A. (2000). Burnout in teachers: shattered dreams of impeccable professional performance. JCLP/In Session, 56(5), 595-606.

Gao, J. H. (2013). Burnout Among Manufacturing Workers in China: The Effects of Organizational Socialization and Leadership Behavior. International Journal of Asian Business and Information Management (IJABIM), 4(2), 11 pages. doi: 10.4018/jabim.2013040103

Goddard, R., \& O’Brien, P. (2004). Are beginning teachers with a second degree at higher risk of early career burnout. Australian Journal of Teacher Education, 29(1), 1-10.

Grayson, J. L., \& Alvarez, H. K. (2008). School climate factors relating to teacher burnout: a mediator model. Teaching and Teacher Education, 24, 1349-1363.

Hakanen, J. J., Bakker, A. B., \& Schaufeli, W. B. (2006). Burnout and work engagement among teachers. Journal of School Psychology, 43, 495-513.

Hennink, M., Hutter, I., \& Bailey, A. (2011). Qualitative Research Methods. London: Sage Publications. Retrieved from http://books.google.de/books?hl=tr\&lr=\&id= zN70kC0 E3XQC\&oi=fnd\&pg=PP2\&dq=qualitative+methods\&ots=HWS60GxGxn\&sig=i2TmqCBRAC5msYjoXgU8izm98Kg\#v=onepage\&q= qualitative\%20methods\&f=false on 10 June 2014.

Haueter, J. A., Macan, T. H., \& Winter, J. (2003). Measurement of newcomer socialization: construct validation of a multidimensional scale. Journal of Vocational Behavior, 63, 20-39.

Hong, J. (2010). Pre-service and beginning teachers' professional identity and its relation to dropping out of the profession. Teaching and Teacher Education, 26, 1530-1543.

Hughes, R. E. (2001). Deciding to leave but staying: teacher burnout, precursors and turnover. The International Journal of Human Resource Management, 12(2), 288-298.

Kanno, Y., \& Stuart, C. (2011). Learning to become a second language teacher: Identities-in-practice. The Modern Language Journal, 95, 236-252.

Kersaint, G., Lewis, J., Potter, R., \& Meisels, G. (2007). Why teachers leave: Factors that influence retention and resignation. Teaching and Teacher Education, 23, 775-794.

Leiter, M. P., \& Maslach, C. (1988). The impact of interpersonal environment on burnout and organizational commitment. Journal of Organizational Behavior, 9, 297-208.

Liang, S., \& Hsieh, A. (2008). The role of organizational socialization in burnout: a Taiwanese example. Social Behavior and Personality: An International Journal, 36(2), 197-216.

Lunenburg, F. C., \& Ornstein, A. C. (2008). Educational administration: Concepts and practices. Belmont, CA: Wadsworth.

Lynn, S. J. (2013). Teacher burnout and its relationships with academic optimism, teacher socialization, and teacher cohesiveness. ETD Collection for Fordham University. Paper AAI3552664. Retrieved from http://fordham.bepress.com/dissertations/AAI355 2664 on 20 June 2014.

Maslach, C. (2003). Job burnout: new directions in research and intervention. Current Directions in Psychological Science, 12, 189-192.

Maslach, C., \& Goldberg, J. (1998). Prevention of burnout: new perspectives. Applied \& Preventive Psychology, 7, 63-74. 
Maslach, C., \& Jackson, S. E. (1981). The measurement of experienced burnout. Journal of Occupational Behavior, 2, 99-113.

Maslach, C., Schaufeli, W. B., \& Leiter, M. P. (2001). Job burnout. Annual Review Psychology, 52, 397-422.

Munthe, E. (2003). Teachers' workplace and professional certainty. Teaching and Teacher Education, 19, 801-813.

Öztürk, G. (2013). Job burnout experienced by Turkish instructors of English at state universities. International Online Journal of Educational Sciences, 5(3), 587-597.

Quartz, K. H., \& The TEP Research Group. (2003). “Too angry to leave”: Supporting new teachers' commitment to transform urban schools. Journal of Teacher Education, 54(2), 99-111.

Richmond, V. P., Wrench, J. C., \& Gorham, J. (2001). Communication, affect, and learning in the classroom. Acton, MA: Tapestry Press.

Rinke, C. R. (2008). Understanding teachers' careers: linking professional life to professional path. Educational Research Review, 3, 1-13.

Schlichte, J., Yssel, N., \& Merbler, J. (2005). Pathways to burnout: case studies in teacher isolation and alienation. Preventing School Failure: Alternative Education for Children and Youth, 50(1), $35-40$.

Shin, S. (2012). "It cannot be done alone": Socialization of novice English teachers in South Korea. TESOL Quarterly, 46(3), 542-567.

Smethem, L. (2007). Retention and intention in teaching careers: will the new generation stay?, Teachers and Teaching: Theory and Practice, 13(5), 465-480.

Skaalvik, E. M., \& Skaalvik, S. (2009). Does school context matter? Relations with teacher burnout and job satisfaction. Teaching and Teacher Education, 25, 518-524.

Skaalvik, E. M., \& Skaalvik, S. (2010). Teacher self-efficacy and teacher burnout: a study of relations. Teaching and Teacher Education, 26, 1059-1069.

Stuart, C., \& Thurlow, D. (2000). Making it their own: Preservice teachers' experiences, beliefs, and classroom practices. Journal of Teacher Education, 51(2), 113-121.

Taormina, R. J., \& Law, C. M. (2000). Approaches to preventing burnout: the effects of personal stress management and organizational socialization, Journal of Nursing Management, 8, 89-99.

Unaldi, I., Bardakci, M., Dolas, F., \& Arpaci, D. (2013). The relationship between occupational burnout and personality traits of Turkish EFL teachers. Journal of Education and Practice, 4(13), $86-98$.

Urzua, A. (1999). Book Review: The socialization process of beginning teachers, Journal of Teacher Education, 50(3), 231-233.

Walsdorf, K. L., \& Lynn, S. K. (2002). The early years: mediating the organizational environment. The Clearing House: A Journal of Educational Strategies, Issues and Ideas, 75(4), 190-194.

Weiss, E. M. (1999). Perceived workplace conditions and first-year teachers' morale, career choice commitment, and planned retention: a secondary analysis. Teaching and Teacher Education, 15, 861-879. 


\section{Appendix A. Teacher burnout scale}

This measure is designed to determine how you currently feel about your job and its related aspects. There are no right or wrong answers. Work quickly and circle your first impression. Please indicate the degree to which each statement applies to you by marking whether you:

Strongly Disagree = 1; Disagree = 2; Neutral = 3; Agree = 4; Strongly Agree = 5

\begin{tabular}{|c|c|c|c|c|c|c|}
\hline & & 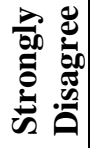 & 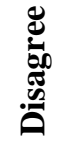 & 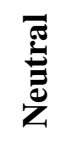 & 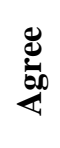 & 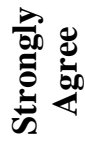 \\
\hline 1. & I am bored with my job. & 1 & 2 & 3 & 4 & 5 \\
\hline 2. & I am tired of my students. & $\mathbf{1}$ & 2 & 3 & 4 & 5 \\
\hline 3. & $\begin{array}{l}\text { I am weary (weary (adjective) - physically or mentally fatigued; } \\
\text { causing fatigue; tiresome) with all of my job responsibilities. }\end{array}$ & 1 & 2 & 3 & 4 & 5 \\
\hline 4. & My job doesn't excite me anymore. & 1 & 2 & 3 & 4 & 5 \\
\hline 5. & I dislike going to my job. & 1 & 2 & 3 & 4 & 5 \\
\hline 6. & $\begin{array}{l}\text { I feel alienated (alienated (adjective) - feeling of not longer } \\
\text { belonging to a particular group, society, etc.) at work. }\end{array}$ & 1 & 2 & 3 & 4 & 5 \\
\hline 7. & I feel frustrated at work. & 1 & 2 & 3 & 4 & 5 \\
\hline 8. & I avoid communication with students. & 1 & 2 & 3 & 4 & 5 \\
\hline 9. & I avoid communication with my colleagues. & 1 & 2 & 3 & 4 & 5 \\
\hline 10. & I communicate in a hostile manner at work. & 1 & 2 & 3 & 4 & 5 \\
\hline 11. & I feel ill at work. & 1 & 2 & 3 & 4 & 5 \\
\hline 12. & I think about calling my students ugly names. & 1 & 2 & 3 & 4 & 5 \\
\hline 13. & I avoid looking at my students. & 1 & 2 & 3 & 4 & 5 \\
\hline 14. & My students make me sick. & 1 & 2 & 3 & 4 & 5 \\
\hline 15. & I feel sick to my stomach when I think about work. & 1 & 2 & 3 & 4 & 5 \\
\hline 16. & I wish people would leave me alone at work. & 1 & 2 & 3 & 4 & 5 \\
\hline 17. & $\begin{array}{l}\text { I dread (dread (verb) - to be in terror of; to anticipate with alarm, } \\
\text { distaste, or reluctance) going to school. }\end{array}$ & 1 & 2 & 3 & 4 & 5 \\
\hline 18. & $\begin{array}{l}\text { I am apathetic (apathetic (adjective) - feeling or showing a lack of } \\
\text { interest or concern; indifferent; feeling or showing little or no } \\
\text { emotion; unresponsive) about my job. }\end{array}$ & 1 & 2 & 3 & 4 & 5 \\
\hline 19. & I feel stressed at work. & 1 & 2 & 3 & 4 & 5 \\
\hline 20. & I have problems concentrating at work. & 1 & 2 & 3 & 4 & 5 \\
\hline
\end{tabular}

\section{Appendix B. English version of the organizational socialization scale}

\begin{tabular}{|c|c|c|c|c|c|}
\hline & 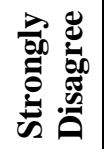 & 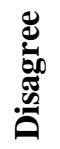 & 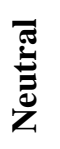 & 递 & 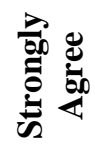 \\
\hline 1. I have learnt my profession in a detailed way. & 1 & 2 & 3 & 4 & 5 \\
\hline 2. I know well the duties my job requires. & 1 & 2 & 3 & 4 & 5 \\
\hline 3. I have learnt how to perform my profession finely/sufficiently. & 1 & 2 & 3 & 4 & 5 \\
\hline 4. I know my responsibilities at my school. & 1 & 2 & 3 & 4 & 5 \\
\hline 5. I know about the regulations related to my profession. & 1 & 2 & 3 & 4 & 5 \\
\hline 6. I attend the social events that my colleagues at school join. & 1 & 2 & 3 & 4 & 5 \\
\hline $\begin{array}{l}\text { 7. I think that I have a good relationship with the personnel } \\
\text { employed in my school. }\end{array}$ & 1 & 2 & 3 & 4 & 5 \\
\hline
\end{tabular}




\begin{tabular}{|l|l|l|l|l|l|}
\hline 8. $\begin{array}{l}\text { My colleagues voluntarily help me with issues concerning my } \\
\text { profession. }\end{array}$ & $\mathbf{1}$ & $\mathbf{2}$ & $\mathbf{3}$ & $\mathbf{4}$ & $\mathbf{5}$ \\
\hline 9. I view most of my colleagues at school as a friend of mine. & $\mathbf{1}$ & $\mathbf{2}$ & $\mathbf{3}$ & $\mathbf{4}$ & $\mathbf{5}$ \\
\hline 10. Everyone at my school likes me. & $\mathbf{1}$ & $\mathbf{2}$ & $\mathbf{3}$ & $\mathbf{4}$ & $\mathbf{5}$ \\
\hline $\begin{array}{l}\text { 11. The majority of my colleagues in my school accept me as a part } \\
\text { of the school }\end{array}$ & $\mathbf{1}$ & $\mathbf{2}$ & $\mathbf{3}$ & $\mathbf{4}$ & $\mathbf{5}$ \\
\hline $\begin{array}{l}\text { 12. I know the customs of my school coming from the past to the } \\
\text { present. }\end{array}$ & $\mathbf{1}$ & $\mathbf{2}$ & $\mathbf{3}$ & $\mathbf{4}$ & $\mathbf{5}$ \\
\hline $\begin{array}{l}\text { 13. I am aware of the past events which were important for my } \\
\text { school. }\end{array}$ & $\mathbf{1}$ & $\mathbf{2}$ & $\mathbf{3}$ & $\mathbf{4}$ & $\mathbf{5}$ \\
\hline $\begin{array}{l}\text { 14. I know about peculiar words (jargon) unique to our school used } \\
\text { by the school employees. }\end{array}$ & $\mathbf{1}$ & $\mathbf{2}$ & $\mathbf{3}$ & $\mathbf{4}$ & $\mathbf{5}$ \\
\hline $\begin{array}{l}\text { 15. I know the meanings of the codes and abbreviations used at my } \\
\text { school. }\end{array}$ & $\mathbf{1}$ & $\mathbf{2}$ & $\mathbf{3}$ & $\mathbf{4}$ & $\mathbf{5}$ \\
\hline $\begin{array}{l}\text { 16. I know the people whose ideas / thoughts are valued / followed } \\
\text { in my school. }\end{array}$ & $\mathbf{1}$ & $\mathbf{2}$ & $\mathbf{3}$ & $\mathbf{4}$ & $\mathbf{5}$ \\
\hline $\begin{array}{l}\text { 17. I understand / am aware of the social interaction pattern (formal } \\
\text { and informal relations) in my school. }\end{array}$ & $\mathbf{1}$ & $\mathbf{2}$ & $\mathbf{3}$ & $\mathbf{4}$ & $\mathbf{5}$ \\
\hline $\begin{array}{l}\text { 18. I know about the valid norms (the behaviour specified and } \\
\text { accepted by informal groups) at my school. }\end{array}$ & $\mathbf{1}$ & $\mathbf{2}$ & $\mathbf{3}$ & $\mathbf{4}$ & $\mathbf{5}$ \\
\hline 19. I obey the rules valid at my school. & $\mathbf{1}$ & $\mathbf{2}$ & $\mathbf{3}$ & $\mathbf{4}$ & $\mathbf{5}$ \\
\hline $\mathbf{2 0 .}$ I support the aims of my school. & $\mathbf{1}$ & $\mathbf{2}$ & $\mathbf{3}$ & $\mathbf{4}$ & $\mathbf{5}$ \\
\hline $\begin{array}{l}\mathbf{2 1} \text { I internalize the values which are imparted to the students by my } \\
\text { school. }\end{array}$ & $\mathbf{1}$ & $\mathbf{2}$ & $\mathbf{3}$ & $\mathbf{4}$ & $\mathbf{5}$ \\
\hline $\begin{array}{l}\text { 22. The goals that are aimed to be reached at my school are clear } \\
\text { and explicit. }\end{array}$ & $\mathbf{1}$ & $\mathbf{2}$ & $\mathbf{3}$ & $\mathbf{4}$ & $\mathbf{5}$ \\
\hline $\begin{array}{l}\text { 23. I believe that the values of my school are in accordance with my } \\
\text { personal values. }\end{array}$ & $\mathbf{1}$ & $\mathbf{2}$ & $\mathbf{3}$ & $\mathbf{4}$ & $\mathbf{5}$ \\
\hline $\mathbf{2 4 . ~ T h e ~ a i m s ~ o f ~ t h e ~ s c h o o l ~ I ~ a m ~ w o r k i n g ~ i n ~ a r e ~ a l s o ~ m y ~ o w n ~ a i m s . ~}$ & $\mathbf{1}$ & $\mathbf{2}$ & $\mathbf{3}$ & $\mathbf{4}$ & $\mathbf{5}$ \\
\hline
\end{tabular}

\section{Appendix C. Turkish version of the organizational socialization scale}

\begin{tabular}{|c|c|c|c|c|c|}
\hline & 昱 & 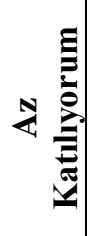 & 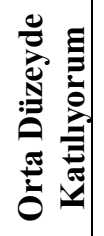 & 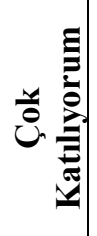 & 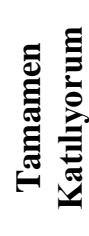 \\
\hline 1. Mesleğimi ince ayrıntılarına kadar öğrendim. & 1 & 2 & 3 & 4 & 5 \\
\hline 2. Mesleğimin gerektirdiği görevleri iyi biliyorum. & 1 & 2 & 3 & 4 & 5 \\
\hline 3. Mesleğimi iyi bir şekilde nasıl yerine getireceğimi öğrendim. & 1 & 2 & 3 & 4 & 5 \\
\hline 4. Okulumdaki sorumluluklarımı biliyorum. & 1 & 2 & 3 & 4 & 5 \\
\hline 5. Mesleğimle ilgili mevzuatı biliyorum. & $\mathbf{1}$ & 2 & 3 & 4 & 5 \\
\hline $\begin{array}{l}\text { 6. Okulumdaki iş arkadaşlarımın katıldığı sosyal etkinliklere ben } \\
\text { de katılırım. }\end{array}$ & 1 & 2 & 3 & 4 & 5 \\
\hline $\begin{array}{l}\text { 7. Okulumda çalışan kişilerle ilişsilerimin iyi olduğunu } \\
\text { düşünüyorum. }\end{array}$ & 1 & 2 & 3 & 4 & 5 \\
\hline $\begin{array}{l}\text { 8. Okulumdaki meslektaşlarım işimle ilgili konularda gönüllü } \\
\text { olarak bana yardım ederler. }\end{array}$ & 1 & 2 & 3 & 4 & 5 \\
\hline $\begin{array}{l}\text { 9. Okulumdaki meslektaşlarımın çoğunu arkadaşım olarak } \\
\text { görüyorum. }\end{array}$ & 1 & 2 & 3 & 4 & 5 \\
\hline 10. Okulumda herkes tarafindan sevilirim. & 1 & 2 & 3 & 4 & 5 \\
\hline $\begin{array}{l}\text { 11. Okulumdaki meslektaşlarımın çoğu beni bu okulun bir parçası } \\
\text { olarak kabul ederler. }\end{array}$ & 1 & 2 & 3 & 4 & 5 \\
\hline
\end{tabular}




\begin{tabular}{|c|c|c|c|c|c|}
\hline 12. Okulumun geçmişten bugüne uzanan geleneklerini biliyorum. & 1 & 2 & 3 & 4 & 5 \\
\hline 13. Okulumun geçmişindeki önemli olayları biliyorum. & 1 & 2 & 3 & 4 & 5 \\
\hline $\begin{array}{l}\text { 14. Okul çalışanlarının kullandığı, okulumuza özgü sözcükleri } \\
\text { biliyorum. }\end{array}$ & 1 & 2 & 3 & 4 & 5 \\
\hline $\begin{array}{l}\text { 15. Okulumda kullanılan kısaltmaların ve kodlamaların anlamlarını } \\
\text { biliyorum. }\end{array}$ & 1 & 2 & 3 & 4 & 5 \\
\hline 16. Okulumda sözü dinlenen kişilerin kimler olduğunu biliyorum. & 1 & 2 & 3 & 4 & 5 \\
\hline $\begin{array}{l}\text { 17. Okulumdaki sosyal etkileşim (formal-informal ilişkiler) } \\
\text { örüntüsünü anllyorum. }\end{array}$ & 1 & 2 & 3 & 4 & 5 \\
\hline $\begin{array}{l}\text { 18. Okulumda geçerli olan normları (informal gruplar tarafindan } \\
\text { belirlenen ve onaylanan davranış kalıpları) biliyorum. }\end{array}$ & 1 & 2 & 3 & 4 & 5 \\
\hline 19. Okulumda geçerli olan kurallara uyarım. & 1 & 2 & 3 & 4 & 5 \\
\hline 20. Okulumun amaçlarını destekliyorum. & 1 & 2 & 3 & 4 & 5 \\
\hline $\begin{array}{l}\text { 21. Okulum tarafindan öğrencilere kazandırılan değerleri } \\
\text { benimsiyorum. }\end{array}$ & 1 & 2 & 3 & 4 & 5 \\
\hline 22. Okulumda ulaşılmaya çalışılan amaçlar açık ve nettir. & $\mathbf{1}$ & 2 & 3 & 4 & 5 \\
\hline $\begin{array}{l}\text { 23. Okulumun değerleri ile kişisel değerlerimin örtüştüğünü } \\
\text { düşünüyorum. }\end{array}$ & 1 & 2 & 3 & 4 & 5 \\
\hline 24. Okulumun amaçları aynı zamanda benim de amaçlarımdır. & $\mathbf{1}$ & 2 & 3 & 4 & 5 \\
\hline
\end{tabular}

\section{Appendix E. Interview questions}

\section{Teacher Socialization}

1. Describe your first day at school. Detail your positive and negative feelings.

(Okulda geçirdiğiniz ilk günü olumlu ve olumsuz yönleriyle anlatınız. Nasıl hissettiniz?)

2. Did you have any orientation problems? Where? In which situation? Why?

(Uyum sorunu yaşadınız mı? Nerede? Hangi durumda? Neden?)

3. Do you have any difficulties with the administration, staff, principal, colleagues, students, school environment, parents? Do you feel suppressed in the teachers' room (e.g. not feeling free to express your thoughts etc.)? (Okul yönetimi, personel, öğretmenler, öğrenciler, okulun çevresi veya velilerle sorun yaşıyor musunuz? Öğretmenler odasında baskı altında kalıyor musunuz (hareketlerin kısıtlanması, düşünceleri dile getirememe gibi)?)

4. Have you received praise for your work? Do you expect praise or other kinds of reward? (Yaptığınız işten dolayı övgü aldınız mı? Övgü veya diğer tür ödüller bekliyor musunuz?)

5. Do you wish to have university connection/ connection with your teacher trainee? Why? (Üniversiteyle iletişim içinde olmak ister miydiniz? Neden?)

6. Do you feel that you belong to your organization? Do you feel accepted as part of your institution? Do others give you the feeling of belonging to it?

(Kendinizi kuruma ait hissediyor musunuz?)

7. Are you pleased with the rules and conventions of your institution? (Okulunuzun kurallarından memnun musunuz?)

8. What are the factors that give you the feeling of satisfaction/ dissatisfaction in your institution? (Kurumunuzda sizi memnun eden/ memnun etmeyen faktörler nelerdir?)

9. How do the experienced teachers cope with you as a novice? Have you ever felt that you are not welcome in the school?

(Deneyimli öğretmenlerin size karşı tutumları nasıl? Okulda istenmediğiniz hissine kapıldınız mı?)

10. In what way has the type and the location of your school, the number of your students, your teaching hours, and extra administrative responsibilities affected you?

(Görev yaptığınız okulun türü ve konumu, öğrenci sayınız, ders saatiniz ve size verilen diğer görevler (sınıf rehber öğretmenliği gibi) sizi nasıl etkiledi?)

\section{Burnout}

1. How do you feel in your job? Do you feel motivated to do your job, improve yourself or do you feel tired or burned out? Why?

(Mesleğinizi yaparken kendinizi nasıl hissediyorsunuz? Neden?) 
2. What changes would you want in your institutions to be more motivated towards your profession? Do you think such changes will happen?

(Kurumunuzda çalışırken motivasyonunuzun artması için ne gibi değişiklikler olmasını gerekli görüyorsunuz? $\mathrm{Bu}$ değişimlerin gerçekleşeceğine inanıyor musunuz?)

3. Have you chosen teaching voluntarily as a profession? If you could choose your occupation today, would you choose to be a teacher? How long do you plan to remain in teaching?

(Mesleği isteyerek mi seçtiniz? Eğer mesleğinizi yeniden şensme şansınız olsaydı, öğretmenliği tekrar seçer miydiniz? Öğretmenliği ne kadar sure yapmayı düşünüyorsunuz?)

4. Did you have any problems during the transition phase from being a student to being a teacher? How much time has your adaptation taken? What do you think were the reasons for these problems?

(Öğrencilikten öğretmenliğe geçiş aşamasında ne gibi zorluklarla karşılaştınız? Okula adaptasyon süreciniz ne kadar sürdü? Bunun nedenleri nelerdi?)

5. Do you believe that the pre-teaching program is sufficient enough for your occupation? If not, what do you recommend to develop pre-teaching programs? Have you felt prepared to teach after your practicum? Did this feeling change after starting working at school?

(Üniversite aldığınız eğitimin mesleğiniz için yeterli olduğunu düşünüyor musunuz? Eğer hayır ise, eğitim fakültesinde ne gibi değişiklikler yapılması gerektiğini düşünüyorsunuz?)

\section{Öğretmen tükenmişliği ve örgütsel sosyalleşme:Türkiye'deki İngilizce öğretmenleri örneklemi}

\section{$\ddot{\mathbf{O} z}$}

Öğretmenler çalışma hayatında stres, iş yükü ve düzensiz sosyal ilişkiler gibi birçok olumsuz etmenle karşılaşmaktadırlar. $\mathrm{Bu}$ ve benzeri faktörler öğretmen tükenmişliğine ve zorlu geçen bir örgütsel sosyalleşme sürecine neden olmaktadır. Bu çalışmanın amacı Türkiye'de görev yapan İngilizce öğretmenlerinin tükenmişlik seviyelerini ve örgütsel sosyalleşme düzeylerini belirlemektir. Ayrıca öğretmen tükenmişliği ve örgütsel sosyalleşme arasında anlamlı bir ilişki olup olmadığını bulmak ve öğretmen tükenmişliğine yol açan etmenler ile sosyalleşme sürecini zorlaştıran faktörleri belirlemek hedeflenmektedir. Çalışmanın amacını gerçekleştirmek üzere nicel ve nitel araştırma yöntemlerinden yararlanılmıştır. Richmond, Wrench ve Gorham (2001) tarafindan geliştirilen "Öğretmen Tükenmişlik Ölçeği’” ile ilk kez araştırmacı tarafindan İngilizceye uyarlanan Erdoğan'ın (2012) “Örgütsel Sosyalleşme Ölçeği”" araştırmanın nicel verilerini; araştırmacının geliş̧tirdiği yarı-yapılandırılmış görüşme ise nitel verileri toplamak için kullanılmıştır. Verilerin analizinde tek-yönlü ANOVA, t-testi, Fisher'in LSD testi, Pearson korelasyon testi ve betimsel istatistiklerden yararlanılmıştır. Bu yöntemlerin yardımıyla elde edilen sonuçlara göre Türkiye'de görev yapan İngilizce öğretmenlerinin tükenmişlik seviyeleri düşük ve örgütsel sosyalleşme düzeyleri yüksek bulunmuştur. Tükenmişlik ve örgütsel sosyalleşme arasında ise ters orantılı bir ilişki gözlenmiştir.

Anahtar sözcükler: İngilizce öğretimi; tükenmişlik; öğretmen tükenmişliği; örgütsel/ kurumsal sosyalleşme; yabancı dil öğretimi

\section{AUTHOR BIODATA}

Çiğdem Güneş started to work for the Ministry of National Education as an English language teacher in 2013 and is teaching English to young learners in a primary school at present. She is currently pursuing her Ph.D. in English Language Teaching at Gazi University, Ankara. Her research interests include foreign language teacher education, second language acquisition, teaching and learning English as a foreign language, and young language learners. 
Hacer Hande Uysal is currently an associate professor at Hacettepe University, the Department of Foreign Language Education. She was the founder and the previous director of the Gazi Academic Writing \& Research Center at Gazi University, where she also worked for twelve years in English Language Teaching Program. She also served as the founding editor-chief in the Journal of Language Teaching and Learning for five years. She received her Ph.D. in Foreign Language/ ESL Education from The University of Iowa. Her research interests are second language writing, intercultural rhetoric, academic discourse, early language teaching, and language planning policy. 